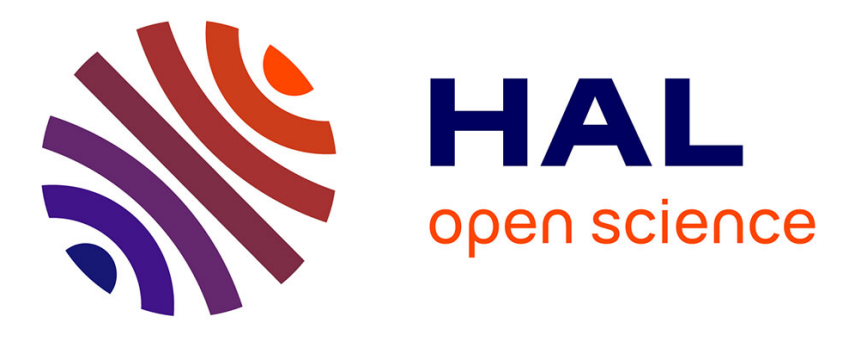

\title{
Chitosan improves stability of carbon nanotube biocathodes for glucose biofuel cells
}

\author{
Sarra El Ichi, Abdelkader Zebda, Awatef Laaroussi, Nadè Ge Reverdy-Bruas, \\ Didier Chaussy, Mohamed Naceur Belgacem, Philippe Cinquin, Donald K \\ Martin
}

\section{To cite this version:}

Sarra El Ichi, Abdelkader Zebda, Awatef Laaroussi, Nadè Ge Reverdy-Bruas, Didier Chaussy, et al.. Chitosan improves stability of carbon nanotube biocathodes for glucose biofuel cells. Journal of the Chemical Society, Chemical Communications, 2014, 50, pp.14535 - 14538. 10.1039/c4cc04862h . hal-01083956

\section{HAL Id: hal-01083956 https://hal.science/hal-01083956}

Submitted on 18 Nov 2014

HAL is a multi-disciplinary open access archive for the deposit and dissemination of scientific research documents, whether they are published or not. The documents may come from teaching and research institutions in France or abroad, or from public or private research centers.
L'archive ouverte pluridisciplinaire HAL, est destinée au dépôt et à la diffusion de documents scientifiques de niveau recherche, publiés ou non, émanant des établissements d'enseignement et de recherche français ou étrangers, des laboratoires publics ou privés. 


\section{ChemComm}

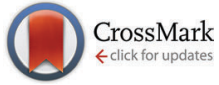

Cite this: Chem. Commun., 2014, 50, 14535

Received 26th June 2014, Accepted 6th October 2014

DOI: $10.1039 / \mathrm{c} 4 \mathrm{cc} 04862 \mathrm{~h}$

www.rsc.org/chemcomm

\section{Chitosan improves stability of carbon nanotube biocathodes for glucose biofuel cells $\dagger$}

\author{
Sarra El Ichi, ${ }^{a}$ Abdelkader Zebda, ${ }^{a}$ Awatef Laaroussi, ${ }^{b}$ Nadège Reverdy-Bruas, ${ }^{b}$ \\ Didier Chaussy, ${ }^{b}$ Mohamed Naceur Belgacem, ${ }^{b}$ Philippe Cinquin ${ }^{a}$ and \\ Donald K. Martin*a
}

We demonstrate a novel combined chitosan-carbon-nanotube-enzyme biocathode with a greatly enhanced and stable long-term current density of $-0.19 \mathrm{~mA} \mathrm{~mL}^{-1}$. The fibrous microstructure of the electrode improves the performance of the biocathode by creating a protective microenvironment, preventing the loss of the electrocatalytic activity of the enzyme, and providing good oxygen diffusion.

A biofuel cell that uses glucose for a fuel (GBFC) relies upon enzymes, such as glucose oxidase or glucose dehydrogenase immobilized at the anode, and enzymes such as laccase, bilirubin oxidase or polyphenol oxidase immobilized at the cathode. The enzymes immobilized at the cathode oxidize glucose to gluconolactone, whereas the enzymes at the anode catalyze the reduction of oxygen to water. ${ }^{1}$ During the last decade the delivered electrical power of these biofuel cell systems has been increased from a few $\mu \mathrm{W} \mathrm{cm} \mathrm{cm}^{-2}$ to a few $\mathrm{mW} \mathrm{cm}{ }^{-2} \cdot{ }^{2-4}$ However, the enzymes used for those biofuel cells have limited stability and a short lifetime, which are factors that restrict their application to routinely provide power for implanted devices.

The operational stability of the GBFC is important not only under storage conditions but also in the case of continuous discharge conditions. Although most of reports in literature describe the performance of GBFCs, few reports address the stability of the biocathodes or bioanodes under conditions of continuous delivered current density. To make GBFCs practical sources of power it is necessary to enhance the stability of the enzymes used for the electrode to months or years. One limitation is due to the complex structure of enzymes and their fragile three dimensional conformations. ${ }^{5}$ Numerous methods have been attempted to increase the lifetime of the biofuel cell by stabilizing the enzyme itself ${ }^{6}$ or by immobilizing the enzyme on the surface of the electrode. ${ }^{2,7}$ Improved immobilization methods and materials for the stability of enzymeelectrode combination remains a major challenge for the practical

\footnotetext{
${ }^{a}$ University of Grenoble Alpes/CNRS/INSERM/TIMC-IMAG UMR 5525

(Equipe SyNaBi), Grenoble, 38000, France.E-mail: don.martin@imag.fr;

Fax: +3347676 8844; Tel: +33456520095

${ }^{b}$ University of Grenoble Alpes/CNRS/LGP2 UMR 5518, F-38000, France

$\dagger$ Electronic supplementary information (ESI) available: Experimental details. See DOI: $10.1039 / \mathrm{c} 4 \mathrm{cc} 04862 \mathrm{~h}$
}

applications of biofuel cells. Immobilization strategies such as physical adsorption, entrapment in conducting polymer matrices, or covalent attachment to functionalized polymers are used mainly to increase enzyme longevity. ${ }^{4}$ However, leaching of enzyme from the electrode in the case of physical adsorption and the modification of enzyme conformation and orientation near the electrode also affect the bioelectrode performance.

The existing best-performing biocathodes are fabricated as disks by compressing multi-walled carbon nanotubes (MWCNT) with laccase. ${ }^{8-10}$ Those existing disk bioelectrodes are able to deliver more

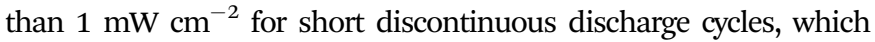
was an output only stable for not more than 1 month when stored in a solution of glucose $(50 \mathrm{mM})$ and saturated oxygen. A GBFC using those biocathodes implanted inside a rat for 8 days was able to deliver $50 \mu \mathrm{W} \mathrm{cm} \mathrm{cm}^{-2}$ during a total of 25 minutes of discharge per hour. ${ }^{8}$ The short lifetime of that GBFC was due to a greater decrease in the performance of the biocathode over time compared to the bioanode. The decrease in the catalytic activity of the biocathode could result from a progressive reorientation or disconnection of the laccase within the MWCNT matrix leading to a decrease in direct electron transfer efficiency. ${ }^{9}$

We report here the novel use of chitosan (Chit) to increase the longevity of a laccase-based biocathode, both under storage conditions and for continuous discharge. Chitosan with a high degree of deacetylation (DD $>85 \%$ ) was chosen as it provides optimal properties in the case of implanted GBFC. Indeed, chitosan with high DD is biocompatible, more stable and degradation is minimised. ${ }^{11}$ Such lower susceptibility to degradation minimises the inflammatory response of the host when the chitosan is implanted. In fact, the inflammatory response can be generated by the accumulation of amino saccharide in the case of rapid degradation of chitosan. A further advantage of a high degree of DD is that the antimicrobial activity of the chitosan is increased, since it is directly proportional to the level of DD. ${ }^{12}$ The antimicrobial activity of chitosan against important pathogens was demonstrated in vivo at neutral $\mathrm{pH}^{13}$ This property of chitosan helps in minimizing the risk of infections if any contamination occurs during the implantation process. 



Fig. 1 SEM image of a cross-section of different biocathodes based on (A) ChitMWCNT, (B) Chit-MWCNT-laccase, (C) MWCNT, (D) MWCNT-laccase. The agglomerates of laccase are the spherical attachments to the chitosan matrix. MWCNT are not visible in chitosan nanofibres presented in (A) and (B). It can be assumed that they are dispersed within the fibres and act as fillers.

Fig. 1A and B shows the SEM image of the fibrous structure of the polymer. The chitosan matrix is composed of nanofibres with diameters varying from 25 to $35 \mathrm{~nm}$. These measured diameters (Fig. 1A) are thicker than those of carbon nanotubes (Fig. 1C) which are more likely tens of nanometers and don't exceed $20 \mathrm{~nm}$. In presence of the enzyme in the matrix, spherical agglomerates were noticed in proximity of the chitosan nanofibres (Fig. 1B) and carbon nanotubes (Fig. 1D). These agglomerates are only visible in the cross-section of electrodes containing the enzyme and not in electrodes used as controls (Fig. 1A and C). These spherical agglomerates are of different sizes (Fig. S1B, ESI $\dagger$ ) and are most likely the laccase enzyme. The obtained composite is a dark black colour which suggests that MWCNT (diameter of $9.5 \mathrm{~nm}$, length of $1.5 \mu \mathrm{m}$ ) were highly dispersed in the porous polymer fibres to act as conducting fillers. The MWCNT cannot be distinguished on a chitosan nanofibre (Fig S1A, ESI $\dagger$ ). It was reported that the diameter of the fibres are influenced by the concentration and the molecular weight of chitosan. Such a nanofibrous structure for chitosan has been reported in literature. ${ }^{14,15}$ The techniques which were used to obtain such structures are generally electrospinning, ${ }^{16,17}$ freeze-drying, ${ }^{18}$ ionic complex or self-organization approaches. ${ }^{19}$ In our case, the chitosan was prepared in an acetic acid solution before being mixed with carbon nanotubes and laccase, then moulded, compressed, and dried at ambient temperature and then stored at $4{ }^{\circ} \mathrm{C}$. The amine groups of chitosan are protonated to $-\mathrm{NH}_{3}^{+}$ in the acidic solution while MWCNT are negatively charged. As a consequence, an electrostatic interaction occurs between the polymer backbone and MWCNT. ${ }^{20}$ The fibrous structure of the chitosan (Chit)-carbon nanotubes (MWCNTs) composite may result after evaporation of the solvent. In fact, the Chit-MWCNT-laccase cathode was dried at ambient temperature. The solvent evaporation method, using organic acids, is one of the enzyme immobilization techniques using chitin- and chitosan-based materials. ${ }^{21}$ It was reported that the presence of carbon nanotubes in the polymer enhances the mechanical properties of the composite. ${ }^{22}$ This may explain the enhancement of the mechanical stability of our biocathode after swelling.
The laccase is not affected by the acidic conditions, since its optimal $\mathrm{pH}$ ranges from 3 to 5 , and it was successfully entrapped within the matrix of chitosan fibres during the preparation of our biocathode. In acidic conditions, the laccase can also be conjugated to chitosan in a first step. Then, when the cathode was immersed in the buffer solution, the change of the local $\mathrm{pH}$ to neutral leads to the precipitation of the polymer-laccase conjugates which coats the carbon nanotubes and thus presents a fibrous structure. The chitosan composition of the nanofibres is revealed by the characteristic positions of peaks as shown by FTIR analysis (Fig. S2, ESI $\dagger$ ). The fingerprint signals of MWCNT are also present which confirms their dispersion in chitosan nanofibres. Fig. S2 (ESI $\dagger$ ) also demonstrates that all free amino groups of chitosan were linked to laccase molecules (see ESI $\dagger$ for details).

Chronoamperometry was used to assess the delivered current density under continuous discharge, at neutral pH in PBS buffer, at ambient temperature and without $\mathrm{O}_{2}$ saturation in order to evaluate the stability of the Chit-MWCNT-laccase biocathode. The average open circuit voltage (OCV) for our biocathode was $0.55 \mathrm{~V}$ vs. SCE, which demonstrates a good electrical connection between the laccase molecules and the conducting chitosan matrix. The continuous chronoamperometric measurement showed a stable current response during 2 months $\left(I \sim-0.19 \mathrm{~mA} \mathrm{~mL}^{-1}\right)$ (curve (a) in Fig. 2). To our knowledge, this is the best stability ever reported for laccase-based biocathode under continuous discharge.

Moreover, the biocathodes exhibited long-term stability in the storage conditions (see ESI $\dagger$ ) considering the chronoamperometric measurements performed under periodic discharge without $\mathrm{O}_{2}$ saturation. The delivered current density was stable for a period of 6 months (curve (b) in Fig. 2). More than $70 \%$ of the initial current density was retained after this period. The delivered current density under continuous discharge is lower than if the cathode is discharged periodically. The reason for that could be that the availability of $\mathrm{O}_{2}$ in the buffer solution decreases when the chronoamperometric measurement is carried out for a long period of time.

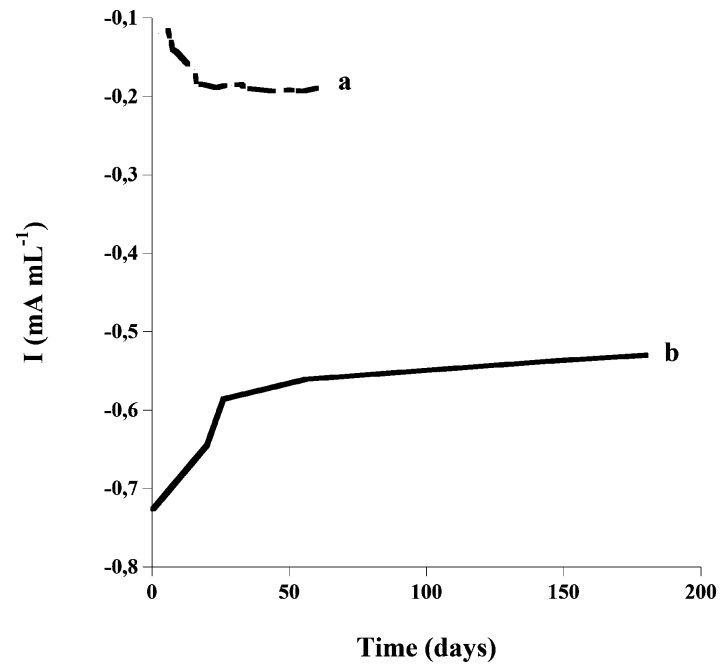

Fig. 2 Stability of the Chit-MWCNT-laccase cathode in phosphate buffered saline solution $\mathrm{pH} 7$ at $0.2 \mathrm{~V}$ vs. SCE (a) under continuous discharge conditions, (b) under storage conditions. 
This enhanced stability of the biocathode was obtained by including the chitosan during the compression of the MWCNT with the laccase, with the MWCNT acting as conducting fillers between the chitosan nanoporous fibres. The porous 3D-polymer matrix allowed a good diffusion of oxygen and enzyme immobilization but also enhanced the mechanical properties of the cathode. The conducting chitosan fibres created a favourable environment for the enzyme with a high surface area and good electrical conductivity. Delanoy and coworkers ${ }^{23}$ demonstrated that the conjugation of laccase with chitosan molecules leads to a high stability, with the conjugated laccase exhibiting the same $\mathrm{pH}$ and temperature profiles as those of free laccase and a similar affinity $\left(K_{\mathrm{m}}\right)$. In our biocathode, the enzyme turnover $\left(k_{\text {cat }}\right)$ was preserved by the use of high molecular weight chitosan with a high degree of deacetylation. The immobilization of the enzyme in a nanostructured 3D material enhanced its stability. It was reported that chloride salts inhibit the laccase activity by raising the ionic strength of the solution. ${ }^{24}$ In the case of our Chit-MWCNT-laccase biocathode, the absence of enzyme inhibition over time could be attributed to the protection of the enzyme by the microenvironment created by the chitosan matrix. In addition, this matrix prevents the enzyme release in the solution. This was confirmed by the measurement of the laccase activity in the buffer solution used for storage (see ESI $\dagger$ for details). After four months, the mean laccase activity in the buffer solution was approximately $0.5 \mathrm{nmol} \mathrm{min}^{-1}$. In the case of the MWCNT-laccase matrix, for the half of this period, the activity loss is three times higher (1.3 nmol $\left.\mathrm{min}^{-1}\right)$. If we consider that the calculated initial enzyme activity which should be theoretically entrapped in the cathode is $272 \mu \mathrm{mol} \mathrm{min}^{-1}$, then the loss in laccase activity after 4 months storage is still negligible. This demonstrates that the enzyme is quite stable when entrapped in the cathode 3D matrix. The enzyme release could thus be attributed to the weakening of the silicon sealing and/or the polymer matrix degradation over time. The MWCNT-laccase cathode is not stable over time since its mechanical properties are affected by the swelling, which weaken the matrix and hence leads to the release of carbon nanotubes and enzyme in the solution.

In order to check if the catalytic current is limited by the biocathode itself or by the $\mathrm{O}_{2}$ concentration and diffusion, chronoamperometric measurements were carried out at $0.2 \mathrm{~V} v s$. SCE under atmospheric $\mathrm{O}_{2}$ concentration and under conditions of $\mathrm{O}_{2}$ saturation.

Fig. 3 shows that the catalytic current increases from $0.8 \mathrm{~mA} \mathrm{~mL}^{-1}$, under atmospheric $\mathrm{O}_{2}$ concentration, to $4.3 \mathrm{~mA} \mathrm{~mL}-1$, after $\mathrm{O}_{2}$ saturation. This result demonstrates that the catalytic current is limited by the $\mathrm{O}_{2}$ concentration and diffusion in the solution. In fact, the saturation of the solution with $\mathrm{O}_{2}$ may increase not only the concentration of $\mathrm{O}_{2}$ near the surface of the electrode but also the diffusion of $\mathrm{O}_{2}$ to the electrode surface. This current is lower compared to the results obtained in a previous report where a MWCNT-laccase cathode delivered a catalytic current of $10 \mathrm{~mA} \mathrm{~mL}{ }^{-1}$ at $0 \mathrm{~V}$ and under $\mathrm{O}_{2}$ saturation. ${ }^{9}$ This difference in the delivered catalytic current could be attributed to the specific surface area of the electrode as well as the available enzyme for the $\mathrm{O}_{2}$ reduction. The specific surface area of the MWCNT matrix, reported in the previous work was five times

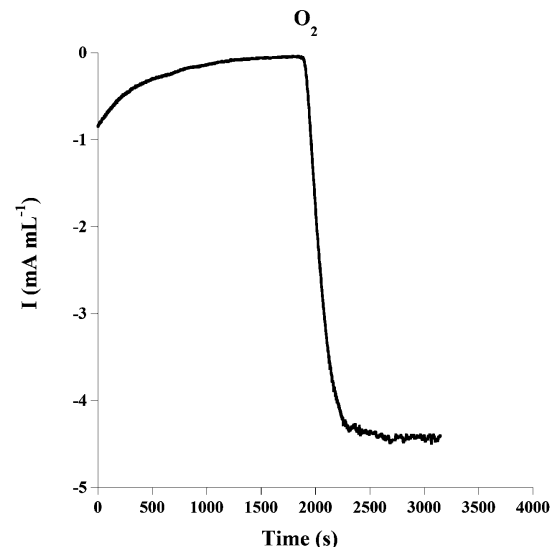

Fig. 3 Chronoamperometric response of Chit-MWCNT-laccase cathode at $0.2 \mathrm{~V}$ vs. SCE, in phosphate buffered saline solution $\mathrm{pH} 7$ under air and $\mathrm{O}_{2}$ saturation.

higher than the one of our Chit-MWCNT-laccase electrode. Indeed, we use chronoamperometric measurements with $\mathrm{Fe}(\mathrm{CN})_{6}$ as the redox probe to estimate the electroactive area of our biocathode (see $\mathrm{ESI} \dagger$ ) and the result shows that the surface area of our electrode is $2 \mathrm{~cm}^{2}$ for $1 \mathrm{~cm}^{2}$ geometric area and $25 \mathrm{mg}$ of MWCNT, which provides an electrochemical specific surface area of $40 \mathrm{~cm}^{2} \mathrm{~g}^{-1}$. This value is one-quarter of that of a MWCNT pellet without chitosan (typically of a specific surface area of $160 \mathrm{~cm}^{2} \mathrm{~g}^{-1}$ ). ${ }^{9}$

To confirm the bioelectrocatalytic origin of registered currents, we made chronoamperometric measurement on electrodes based on Chit-MWCNT without laccase as controls. The measured OCV was 0.14 V vs. SCE for the Chit-MWCNT cathode and Fig. S3 (ESI $\dagger$ ) shows that in absence of laccase, the current output was nearly zero. These results demonstrate that chitosan and MWCNT don't exhibit any electrocatalytic activity.

As shown in Fig. S5 (ESI $\dagger$ ), the chronoamperometric response of the biocathode decreased dramatically in presence of the laccase inhibitor sodium fluoride, which confirms the bioelectrocatalytic origin of the output current.

Most previous reports described the use of chemical crosslinking methods to enhance the storage stability of the cathodes for biofuel cells applications. In the work reported by Nazaruk and coworkers, ${ }^{25}$ single walled nanotubes (SWNTs) were functionalized with linkers of different length and terminated with amino groups, and then treated with glutaraldehyde for laccase conjugation. The SWNTs-laccase conjugates remain active for several months, but the continuous working stability was investigated for just $3 \mathrm{~h}$. Although the advantages of using new materials, ${ }^{7}$ encapsulating materials ${ }^{26}$ and $3 \mathrm{D}$ conducting structures ${ }^{4}$ for biofuel cell applications have been debated in the literature, the continuous chronoamperometric measurement that we report has not been utilised previously for assessing the stability of the biocathode. Indeed, only a few reports can be found that describe the long-term stability of laccase-based electrodes. Vaz-Dominguez and coworkers ${ }^{27}$ evaluated the stability of T. hirsuta laccase (homologous structure to T. versicolor) covalently bound to an aminophenyl electrode under continuous operation in acetate buffer (50 mM, pH 4.2), $\mathrm{NaClO}_{4}(100 \mathrm{mM})$. The applied potential was $+200 \mathrm{mV} v s$. $\mathrm{Ag} / \mathrm{AgCl} / 3 \mathrm{M} \mathrm{KCl}$ at a temperature of $27^{\circ} \mathrm{C}$ 
and the solution was stirred with a magnetic bar. Results showed that about $75 \%$ of the direct electrocatalytic initial current was retained after 10 days. Stolarczyk and coworkers ${ }^{28}$ have designed nanostructured electrodes based on carbon nanotubes, laccase and lecithin. The current density measured at $0.2 \mathrm{~V}$ was $40 \mu \mathrm{A} \mathrm{cm} \mathrm{cm}^{-2}$ in dioxygen saturated solution. The stability of the electrode decreased over time due to the enzyme leaching from the surface to the solution.

It is difficult to preserve the catalytic properties of laccases in physiological conditions. In fact, the optimum $\mathrm{pH}$ of most of laccases is in the range 3-5 and their activity decrease in both physiological $\mathrm{pH}$ and in the presence of chloride. On the contrary, for the case of implantation applications, the laccase-based biocathode must be operational and stable in physiological conditions. Therefore, an immobilization strategy such as we report is crucial for efficient direct electron transfer. In comparison to our results, $\mathrm{Li}$ and co-workers $^{29}$ reported a storage stability of only 10 days for a platinum nanoparticles-laccase-based biocathode. The stability of grafted electrodes, with laccase attached covalently to electropolymerized aminopyrrole, when stored in phosphate buffer $\mathrm{pH} 7$ at $4{ }^{\circ} \mathrm{C}$ was studied by Merle and co-workers. ${ }^{30}$ They observed a maximal value of the laccase activity after 30 days. After this period, the enzyme activity loss depended on the thickness of the polymer. They noticed a $50 \%$ loss in activity in the case of using thinner polymer films.

A previous report indicated that laccase from Tramates versicolor exhibits high activity between $\mathrm{pH} 4.1$ and 4.8 with a maximum at $\mathrm{pH}$ 4.5. The activity is reduced by $57.2 \%$ after $48 \mathrm{~h}$ at $\mathrm{pH}$ 7. The enzyme has optimum temperature in the range of 40-60 ${ }^{\circ} \mathrm{C} .{ }^{31}$ Stoilova and collaborators assayed the thermal stability of laccase in the range of $30-60{ }^{\circ} \mathrm{C}$ and found that the greatest stability of the enzyme is at $30{ }^{\circ} \mathrm{C}$. In our case, the laccase activity and stability can be explained by the role of the Chit-MWCNT matrix in varying the local $\mathrm{pH}$ and in forming a stabilizing microenvironment for the enzyme. In addition, chitosan acts as an immobilization support for laccase molecules either by encapsulation or the formation of amine bonds between the enzyme and the polymer. Chitosan has been reported stabilise laccase by the formation of hydrogen bridges between the chitosan and amino acids of laccase as well as electrostatic interactions. ${ }^{23,32}$ Vazquez-Duhalt and collaborators ${ }^{33}$ demonstrated that conjugation of laccase with chitosan enhances the stability of laccase under extreme base conditions. They reported that the laccase remained fully stable at $\mathrm{pH} 12$.

We demonstrated the potential use of our Chit-MWCNTlaccase biocathode as an implantable electrode, by assaying its operation in sheep serum at $37{ }^{\circ} \mathrm{C}$. The biocathode was able to deliver $-0.17 \mathrm{~mA} \mathrm{~mL}^{-1}$ during $48 \mathrm{~h}$ (Fig. S6, ESI $\dagger$ ). The result was reproducible as the three biocathodes retained 70 to $100 \%$ of the current output measured in phosphate buffer $\mathrm{pH}$ 7. The measured OCV in serum was between 0.48 and $0.5 \mathrm{~V} v s$. SCE for all electrodes.

We report a new strategy to incorporate chitosan into the design of novel bioelectrodes. The results of our investigations demonstrate that a significant increase in longevity and stability of laccase-based biocathodes. This work reports the longest period of stability ever tested especially at neutral $\mathrm{pH}$ and in presence of chloride ions. Moreover, the incorporation of chitosan improves the biocompatibility of the bioelectrodes which is advantageous for use in implantable biofuel cells.

We thank the ANR (MGBFC-EMMA-043, 2011-2013) and the Investissements d'Avenir (ANR-10-NANO-03-01, 2012-2016) for financial support. We thank Frédéric Charlot (CMTC, Grenoble) for producing the SEM images.

\section{Notes and references}

1 I. Ivanov, T. Vidaković-Koch and K. Sundmacher, Energies, 2010, $3,803$.

2 E. H. Yu and K. Scott, Energies, 2010, 3, 23.

3 D. Leech, P. Kavanagh and W. Schuhmann, Electrochim. Acta, 2012, 84, 223.

4 T. Tamaki, Top. Catal., 2012, 55(16-18), 1162.

5 S. D. Minteer, B. Y. Liaw and M. J. Cooney, Curr. Opin. Biotechnol., 2007, 18, 1.

6 Z. Zhu, C. Momeu, M. Zakhartsev and U. Schwaneberg, Biosens. Bioelectron., 2006, 21, 2046.

7 S. D. Minteer, P. Atanassov, H. R. Luckarift and G. R. Johnson, Mater. Today, 2012, 15(4), 166.

8 P. Cinquin, C. Gondran, F. Giroud, S. Mazabrard, A. Pellissier, F. Boucher, J.-P. Alcaraz, K. Gorgy, F. Lenouvel, S. Mathé, P. Porcu and S. Cosnier, PLoS One, 2010, 5(5), e10476.

9 A. Zebda, C. Gondran, A. Le Goff, M. Holzinger, P. Cinquin and S. Cosnier, Nat. Commun., 2011, 2, 370.

10 B. Reuillard, A. Le Goff, C. Agnès, M. Holzinger, A. Zebda, C. Gondran, K. Elouarzaki and S. Cosnier, Phys. Chem. Chem. Phys., 2013, 15, 4892.

11 C. K. S. Pillai, W. Paul and C. P. Sharma, Prog. Polym. Sci., 2009, 34, 641.

12 M. Dash, F. Chiellini, R. M. Ottenbrite and E. Chiellini, Prog. Polym. Sci., 2011, 36, 981.

13 S. J. Jeon, M. Oh, W.-S. Yeo, K. N. Galvão and K. C. Jeong, PLoS One, 2014, 9, e92723.

14 R. Jayakumar, M. Prabaharan, S. V. Nair and H. Tamura, Biotechnol. Adv., 2010, 28, 142.

15 M. Z. Elsabee, H. F. Naguib and R. E. Morsi, Mater. Sci. Eng., C, 2012, 32, 1711.

16 L. Li and Y.-L. Hsieh, Carbohydr. Res., 2006, 341, 374.

17 K. Ohkawa, K.-I. Minato, G. Kumagai, S. Hayashi and H. Yamamoto, Biomacromolecules, 2006, 7(11), 3291.

18 M. Y. Kim and J. Lee, Carbohydr. Polym., 2011, 84, 1329.

19 A. K. Dutta, N. Kawamoto, G. Sugino, H. Izawa, M. Morimoto, H. Saimoto and S. Ifuku, Carbohydr. Polym., 2013, 97, 363-367.

20 T. Zhao, G. Li, L. Liu and T. Liu, Fullerenes, Nanotubes, Carbon Nanostruct., 2011, 19(5), 452.

21 B. Krajewska, Enzyme Microb. Technol., 2004, 35, 126.

22 X. Cao, H. Dong, C. M. Li and L. A. Lucia, J. Appl. Polym. Sci., 2009, $113,466$.

23 G. Delanoy, Q. Li and J. Yu, Int. J. Biol. Macromol., 2005, 35, 89.

24 S. R. Couto and J. L. Toca, Curr. Enzyme Inhib., 2006, 2(4), 343.

25 E. Nazaruk, M. Karaskiewicz, K. Żelechowska, J. F. Biernat, J. Rogalski and R. Bilewicz, Electrochem. Commun., 2012, 14, 67.

26 E. Farneth and M. B. D'Amore, J. Electroanal. Chem., 2005, 581, 197.

27 C. Vaz-Dominguez, S. Campuzano, O. Rüdiger, M. Pita, M. Gorbacheva, S. Shleev, V. M. Fernandez and A. L. De Lacey, Biosens. Bioelectron., 2008, 24, 531.

28 K. Stolarczyk, E. Nazaruk, J. Rogalski and R. Bilewicz, Electrochim. Acta, 2008, 53, 3983.

29 Y. Li, S.-M. Chen, W.-C. Chen, Y.-S. Li, M. A. Ali and F. M. A. AlHemaid, Int. J. Electrochem. Sci., 2011, 6, 6398.

30 G. Merle, L. Brunel, S. Tingry, M. Cretin, M. Rolland, K. Servat, C. Jolivalt, C. Innocent and P. Seta, Mater. Sci. Eng., C, 2008, 28, 932.

31 I. Stoilova, A. Krastanov and V. Stanchev, Adv. Biosci. Biotechnol., 2010, 1, 208.

32 H. Cabana, A. Ahamed and R. Leduc, Bioresour. Technol., 2011, 102, 1656.

33 R. Vazquez-Duhalt, R. Tinoco, P. D'Antonio, L. D. Timmie Topoleski and G. F. Payne, Bioconjugate Chem., 2001, 12, 301. 